\title{
Dysnatraemias in the emergency room: Undetected, untreated, unknown?
}

\author{
Spyridon Arampatzis ${ }^{1}$, Aristomenis Exadaktylos², Daniela Buhl ${ }^{3}$, Heinz Zimmermann², Gregor Lindner ${ }^{1,4}$ \\ ${ }^{1}$ Department of Nephrology and Hypertension, Inselspital, University of Bern, Bern, Switzerland \\ ${ }^{2}$ Department of Emergency Medicine, Inselspital, University of Bern, Bern, Switzerland \\ ${ }^{3}$ Department of Laboratory Medicine, Inselspital, University of Bern, Bern, Switzerland \\ ${ }^{4}$ Department of Internal Medicine, Inselspital, University of Bern, Bern, Switzerland
}

Received August 22, 2011, accepted after revision November 20, 2011, published online December 21, 2011

\section{Dysnatriämien an der Notfallaufnahme: Unentdeckt, unbehandelt, unbekannt?}

Zusammenfassung. Hintergrund: Hypo- und Hypernatriämie sind die häufigsten Elektrolytstörungen im Krankenhaus und wurden mit erhöhter Mortalität assoziiert. Zur Zeit gibt es nur wenige Daten zur Prävalenz der Dysnatriämien an der Notfallaufnahme sowie zu den Charakteristika der Patienten mit Hypo- und Hypernatriämien.

Methodik: In diese retrospektive Studie wurden Patienten welche zwischen 01.09.2010 und 30.11.2010 an der Notfallaufnahme einer Universitätsklinik eine Bestimmung des Serum-Natriums erhielten eingeschlossen.

Resultate: Insgesamt wurden während des Studienzeitraumes an 3.182 Patienten Bestimmungen des Serum-Natriums durchgeführt. 124 Patienten (4\%) wiesen bei Aufnahme in die Notfallaufnahme eine Hyponatriämie auf, während 400 Patienten (13\%) eine Hypernatriämie aufwiesen. Es zeigte sich kein Unterschied im Alter zwischen jenen Patienten welche eine Hypernatriämie aufwiesen und jenen welche normonaträm waren. Patienten mit Hyponatriämie waren hingegen signifikant älter.

Schlussfolgerungen: Beinahe 1 von 5 Patienten weist bei Aufnahme an der Notfallaufnahme eine Störung des Natriumhaushalts auf. Im Gegensatz zu hospitalisierten Patienten war an der Notfallaufnahme die Prävalenz der Hypernatriämie bedeutend grösser als jene der Hyponatriämie. Überraschenderweise waren Patienten mit Hyponatriämie signifikant älter als jene mit Hypernatriämie und jene mit normalen Serum-Natriumwerten.

Summary. Background: Hypo- and hypernatraemia are the most common electrolyte disorders in hospitalized patients and have been associated with increased mortality.

Correspondence: Aristomenis Exadaktylos MD, Associate Professor, Department of Emergency Medicine, Inselspital, University of Bern, Freiburgstrasse, 3010 Bern, Switzerland,

E-mail: aristomenis.exadaktylos@insel.ch
However, data on the prevalence of dysnatraemias in the emergency room and the characteristics of patients presenting with them are rare.

Methods: In this retrospective study, we analyzed data from patients who presented to the emergency department of a large tertiary university hospital between September 1st 2010 and November 30th 2010 and who received measurement of serum sodium.

Results: 3,182 patients received measurement of serum sodium during the three-month study period. 124 patients (4\%) presented with hyponatraemia on admission to the emergency department while 400 patients (13\%) presented with hypernatraemia. While there was no difference in age between patients with hypernatraemia and those who were normonatraemic, patients with hyponatraemia were significantly older.

Conclusion: Dysnatraemias are present in almost 1 in 5 patients who presented to the emergency department. Contrarily to patients who are already hospitalized, hypernatraemia was by far more common than hyponatraemia in patients at the emergency department. Surprisingly, patients with hyponatraemia were significantly older than normonatraemic patients while there was no age difference in hypernatraemic patients. Dysnatraemias are common in the emergency room and further studies are indicated to evaluate the causes and the impact on outcome of patients.

Key words: Hyponatremia, hypernatremia, emergency room, sodium, prevalence, elderly patients.

\section{Introduction}

Dysnatraemias are common in critically ill patients on admission to the intensive care unit (ICU) [1]. Both hypoand hypernatraemia present on admission to the ICU have been associated with substantially increased mortality, independent of age, sex, type of diagnosis on admission and severity of disease as quantified by the severe acute 
physiology score (SAPS) II [1]. Interestingly, this association extended to only minimal deviations of serum sodium from the normal range. However, there is a lack of studies on dysnatremias in the emergency room collective.

Recently, patients with hyponatraemia have been associated with an increased susceptibility to falls [2]. It was also shown that hyponatraemia leads to a reduction in bone mass, termed hyponatraemia-induced osteoporosis [3]. This vicious cycle of increased tendency to fall and higher fracture risk due to reduced bone mass has recently been described in several epidemiological studies [4-6]. These changes were also seen with only mild deviations of serum sodium from the normal range. By contrast, complications of hypernatraemia and consequent hyperosmolality are manifold, and include decrease in cardiac contractility, decreased glucose utilization, insulin resistance, cognitive impairment and cerebral shrinkage leading to vascular rupture [7-12].

Amongst many recent studies on hypo- and hypernatraemia in critically ill patients $[1,13-18]$, the prevalence of hyponatraemia on admission to an emergency room has been investigated in only one study performed in Taiwan [19]. To our knowledge, no study has been conducted to investigate the prevalence of hypo- and hypernatraemia in the emergency room setting in Europe or North America.

\section{Patients, materials and methods}

We analysed sodium values measured over a three-month period (1 September 2010 to 30 November 2010) in patients admitted to the Department of Emergency Medicine of the Inselspital, University Hospital Bern, Switzerland. The distribution of dysnatraemia by age and sex of the patients was also evaluated. In accordance with the normal range in use by the local central laboratory that performed the measurements, hyponatraemia was defined as $<132 \mathrm{mmol} / \mathrm{L}$ and hypernatraemia as $>142 \mathrm{mmol} / \mathrm{L}$ (normal range at central laboratory of our institution).
All results are given as means and standard deviation (SD).

\section{Results}

3,182 patients (mean age 53 years [SD 21], 57\% male, $43 \%$ female) were included in this analysis. Serum sodium values were in the range $111-153 \mathrm{mmol} / \mathrm{L}$, with a mean of 139 $\mathrm{mmol} / \mathrm{L}$ (SD 4). Of all these admissions, 1404 (44\%) were for surgical causes and 1778 (56\%) for medical causes.

Figure 1 shows the distribution of serum sodium on admission to the emergency room over the three-month period.

524 (17\%) of all patients showed dysnatraemia on admission. 124 (4\%) patients (mean age 64 years [SD 16], 56\% male, $44 \%$ female) were hyponatraemic, with a mean serum sodium of $127 \mathrm{mmol} / \mathrm{L}$ (SD 4). 400 patients (13\%) were hypernatraemic (mean age 53 years [SD 22], 59\% male, $41 \%$ female), with a mean serum sodium of 144 $\mathrm{mmol} / \mathrm{L}$ (SD 2). Of the 124 hyponatraemic admissions, 40 (32\%) were admitted for surgical and 84 (68\%) for medical reasons. Of the 400 patients with hypernatraemia $182(46 \%)$ were of a surgical type of admission and 218 (54\%) of a medical type. 4 patients (1\%) during the study period had hypernatraemia as their main admission diagnosis and were neurologically symptomatic on admission. 15 patients $(12 \%)$ were admitted during the study period with hyponatraemia as their main diagnosis with $8(6 \%)$ of them being neurologically symptomatic on admission.

Hyponatraemic patients were significantly older (64 years) than patients either with normonatraemia ( 53 years) or hypernatraemia (53 years); $p<0.01$ in each case.

\section{Discussion}

In this study we describe for the first time the prevalence of dysnatraemia in a large group of patients visiting the

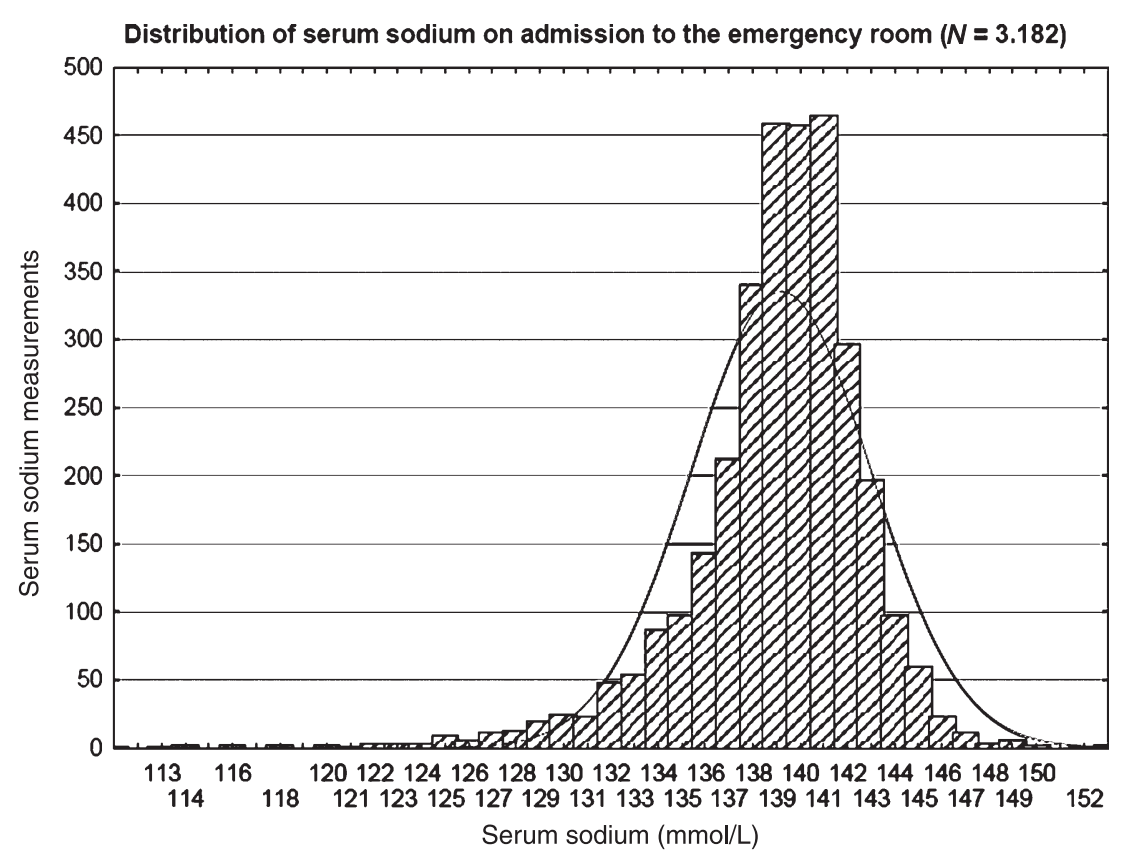

Fig. 1. Distribution of serum sodium on admission to the emergency room over three months $(N=3.182)$ 
emergency room of a large tertiary care hospital in Europe. Hypernatraemia was much more common than hyponatraemia ( $13 \%$ versus $4 \%$ of total patients).

Dysnatraemias have been identified as the most common electrolyte disorders in hospitalized patients $[12,20]$. Hypernatraemia is a common occurrence in the critical care setting because most patients are unconscious, intubated or sedated and frequently have no free access to water $[13,14]$. However, hyponatraemia is also commonly observed in critically ill patients. Pain, medication and central nervous system damage due to trauma, surgery or bleeding often lead to inadequate vasopressin secretion, with consequent retention of free water [20,21]. This might explain the high incidence of hyponatraemia reported in ICU patients $[15,16]$.

All of the above possible causes of hypo- and hypernatraemia may apply to emergency room patients. However, so far, only one study in Taiwan has investigated the prevalence of hyponatraemia in an emergency room [19]. As in the present study, Lee et al. described a prevalence of hyponatraemia (defined as a serum sodium $<134 \mathrm{mmol} / \mathrm{L}$ ) of $4 \%$. The authors also found that mortality increased with decreasing serum sodium levels. Interestingly, hypernatraemia was far more common than hyponatraemia in patients admitted to the ICU, although it was mild in most cases.

Hypernatraemia is generally described as a problem of the elderly who live in nursing homes and have no free access to water, or a reduced sensation of thirst and thus a reduction in water intake $[22,23]$.

However, in the present study, while there was no difference in age between patients with normal serum sodium values and patients with hypernatraemia, hyponatraemic patients were significantly older. This might be explained by the increasing use of diuretics in an aging population: thiazide diuretics have been considered responsible for a significant number of cases of hyponatraemia in an ambulatory setting beside neurological reasons [24-26].

Our study, though limited by its retrospective design, can be considered a pilot study to estimate the incidence of patients presenting with dysnatraemia in the emergency room of a large university hospital.

In conclusion, hypo- and hypernatraemia are common in the emergency room. Interestingly, hypernatraemia was much more common (13\%) than hyponatraemia (4\%) and patients with hyponatraemia were significantly older than patients with normo- or hypernatraemia. Future studies should focus on the aetiology of hypo- and hypernatraemia in these patients and on plans for their management.

\section{Conflict of interest}

None of the authors has a conflict of interest.

\section{References}

1. Funk GC, Lindner G, Druml W, et al. Incidence and prognosis of dysnatremias present on ICU admission. Intensive Care Med 2010;36:304-11.

2. Renneboog B, Musch W, Vandemergel X, Manto MU, Decaux G. Mild chronic hyponatremia is associated with falls, unsteadiness, and attention deficits. Am J Med 2006;119:71 e1-8.
3. Verbalis JG, Barsony J, Sugimura Y, et al. Hyponatremia-induced osteoporosis. J Bone Miner Res;25:554-63.

4. Hoorn EJ, Rivadeneira F, van Meurs JB, et al. Mild hyponatremia as a risk factor for fractures: The Rotterdam Study. J Bone Miner Res 2011;26(8):1822-8.

5. Kinsella S, Moran S, Sullivan MO, Molloy MG, Eustace JA. Hyponatremia independent of osteoporosis is associated with fracture occurrence. Clin J Am Soc Nephrol 5:275-80.

6. Sandhu HS, Gilles E, DeVita MV, Panagopoulos G, Michelis MF. Hyponatremia associated with large-bone fracture in elderly patients. Int Urol Nephrol 2009;41:733-7.

7. Lenz K, Gossinger H, Laggner A, Druml W, Grimm G, Schneeweiss B. Influence of hypernatremic-hyperosmolar state on hemodynamics of patients with normal and depressed myocardial function. Crit Care Med 1986;14:913-4.

8. Kozeny GA, Murdock DK, Euler DE, et al. In vivo effects of acute changes in osmolality and sodium concentration on myocardial contractility. Am Heart J 1985;109:290-6.

9. Bratusch-Marrain PR, DeFronzo RA. Impairment of insulinmediated glucose metabolism by hyperosmolality in man. Diabetes 1983;32:1028-34.

10. Komjati M, Kastner G, Waldhausl W, Bratusch-Marrain P. Detrimental effect of hyperosmolality on insulin-stimulated glucose metabolism in adipose and muscle tissue in vitro. Biochem Med Metab Biol 1988;39:312-8.

11. Komjati M, Kastner G, Waldhausl W, Bratusch-Marrain P. Effect of hyperosmolality on basal and hormone-stimulated hepatic glucose metabolism in vitro. Eur J Clin Invest 1989;19:128-34.

12. Adrogue HJ, Madias NE. Hypernatremia. N Engl J Med 2000;342:1493-9.

13. Lindner G, Funk GC, Lassnigg A, et al. Intensive care-acquired hypernatremia after major cardiothoracic surgery is associated with increased mortality. Intensive Care Med 2010;36:1718-23.

14. Lindner G, Funk GC, Schwarz C, et al. Hypernatremia in the critically ill is an independent risk factor for mortality. Am J Kidney Dis 2007;50:952-7.

15. Stelfox HT, Ahmed SB, Khandwala F, Zygun D, Shahpori $\mathrm{R}$, Laupland $\mathrm{K}$. The epidemiology of intensive care unitacquired hyponatraemia and hypernatraemia in medicalsurgical intensive care units. Crit Care 2008;12:R162.

16. Stelfox HT, Ahmed SB, Zygun D, Khandwala F, Laupland K. Characterization of intensive care unit acquired hyponatremia and hypernatremia following cardiac surgery. Can J Anaesth 2010;57:650-8.

17. Darmon M, Timsit JF, Francais A, et al. Association between hypernatraemia acquired in the ICU and mortality: a cohort study. Nephrol Dial Transplant 2010;25:2510-5.

18. Hoorn EJ, Betjes MG, Weigel J, Zietse R. Hypernatraemia in critically ill patients: too little water and too much salt. Nephrol Dial Transplant 2008;23:1562-8.

19. Lee CT, Guo HR, Chen JB. Hyponatremia in the emergency department. Am J Emerg Med 2000;18:264-8.

20. Adrogue HJ, Madias NE. Hyponatremia. N Engl J Med 2000;342:1581-9.

21. Ellison DH, Berl T. Clinical practice. The syndrome of inappropriate antidiuresis. N Engl J Med 2007;356:2064-72.

22. Hawkins RC. Age and gender as risk factors for hyponatremia and hypernatremia. Clin Chim Acta 2003;337:169-72.

23. Himmelstein DU, Jones AA, Woolhandler S. Hypernatremic dehydration in nursing home patients: an indicator of neglect. J Am Geriatr Soc 1983;31:466-71.

24. Clayton JA, Le Jeune IR, Hall IP. Severe hyponatraemia in medical in-patients: aetiology, assessment and outcome. QJM 2006;99:505-11.

25. Clayton JA, Rodgers S, Blakey J, Avery A, Hall IP. Thiazide diuretic prescription and electrolyte abnormalities in primary care. Br J Clin Pharmacol 2006;61:87-95.

26. Mann SJ. The silent epidemic of thiazide-induced hyponatremia. J Clin Hypertens (Greenwich) 2008;10:477-84. 